\title{
Effects of combined epidural analgesia with total intravenous anesthesia on risky patients underwent major abdominal surgery
}

\author{
Majör abdominal cerrahi uygulanan yüksek riskli hastalarda \\ total intravenöz anestezi ile kombine epidural analjezinin etkileri
}

\author{
Tülin AKARSU AYAZOĞLU, ${ }^{1}$ Aynur ÖZENSOY, ${ }^{2}$ Fatih Doğu GEYIK, ${ }^{3}$ \\ Muhittin ÇALIM, ${ }^{4}$ Uğur DUMAN, ${ }^{5}$ Mehmet Akif CANDAN $^{6}$
}

\begin{abstract}
Summary
Objectives: The aim of this study is to investigate the effects of combined epidural analgesia with total intravenous anaesthesia and only total intravenous anaesthesia on the different clinical parameters.

Methods: Sixty high risk patients undergoing a major abdominal surgical procedure were included in this prospective, double blind, randomized study. Induction of anaesthesia was performed with IV remifentanil $0.5 \mu \mathrm{g} / \mathrm{kg}$ and propofol titrated to achieve bispectral index score between 40 and 50. after intubation; in Group E, $0.1 \%$ bupivacaine and $2 \mu \mathrm{g} / \mathrm{mL}$ fentanyl were administered by an infusion rate at $0.15 \mathrm{ml} / \mathrm{kg} / \mathrm{h}$ via the epidural catheter and Group C received epidural normal saline as same infusion rate.
\end{abstract}

Results: In group $E$, intraoperative MAP values were significantly lower than those in group $C(p<0.05)$. Time of extubation, time of eye opening with audible warning and time of verbal response was significantly lower in group $E$ than those in group C. Total anaesthetic drug consumption was significantly higher in group $C$ than those in group $E(p<0.05)$.

Conclusion: Based on lower requirements for propofol and remifentanil as well as the favourable effects on clinical parameters; we conclude that bispectral index score guided combined epidural with total intravenous anaesthesia is superior to solely total intravenous anaesthesia in this type of surgery.

Keywords: Analgesia; bupivacaine; epidural; fentanyl; remifentanil.

\section{Özet}

Amaç: Bu çalışmanın amacı, farklı klinik parametreler üzerinde sadece total intravenöz anestezi ve total intravenöz anestezi ile kombine epidural analjezinin etkilerini araştırmaktır.

Gereç ve Yöntem: Bu prospektif, çift kör, randomize çalışmaya majör abdominal cerrahi geçirecek yüksek riskli 60 hasta dahil edildi. Anestezi indüksiyonu; IV remifentanil $0.5 \mathrm{mg} / \mathrm{kg}$ ve 40 ile 50 arasında bispektral indeks elde edilecek halde titre edilmiş propofol ile yapıldı. Entübasyon sonrası; Grup E için $0.1 \%$ bupivkain and $2 \mu \mathrm{g} / \mathrm{ml}$ fentanil infüzyon hızı $0.15 \mathrm{ml} / \mathrm{kg} / \mathrm{h}$ olacak şekilde epidural kataterden başlandı. Grup C'ye ise aynı hızda serum salin infüzyonu başlandı.

Bulgular: Intraoperatif ortalama arter basınçları Grup E'de Grup $C^{\prime} y e$ oranla düşük bulundu ( $\left.p<0.05\right)$. Ekstübasyon süresi, göz açma ve sözel cevap süresi Grup E'de Grup C'ye oranla düşük bulundu $(p<0.05)$. Total anestezik ilaç tüketimi Grup C'de Grup E'ye göre daha yüksek bulundu ( $\mathrm{p}<0.05)$.

Sonuç: Düşük doz remifentanil ve propfol kullanımının klinik parametreler üzerine olumlu etkilerine dayanarak; bispektral indeks klavuzluğunda kombine epidural analjezi ve total intravenöz anestezinin tek başına total intravenöz anesteziye oranla daha üstün olduğunu öne sürmekteyiz.

Anahtar sözcükler: Analjezi; bupivakain; epidural; fenatanil; remifentanil.

\footnotetext{
'Department of Anaesthesiology and Reanimation, Istanbul Medeniyet University,

Goztepe Training and Research Hospital, Istanbul, Turkey

2Department of Anaesthesiology and Reanimation, Kartal Kosuyolu High Speciality Training and Research Hospital, Istanbul, Turkey

${ }^{3}$ Department of Anaesthesiology and Reanimation, Kartal Lutfi Kirdar Training and Research Hospital, Istanbul, Turkey

${ }^{4}$ Department of Anaesthesiology and Reanimation, Bezmi Alem Vakif University Faculty of Medicine Hospital, Istanbul, Turkey

${ }^{5}$ Department of General Surgery, Sevket Yilmaz Training and Research Hospital, Bursa, Turkey

${ }^{6}$ Department of Anaesthesiology and Reanimation, Rize State Hospital, Rize, Turkey

Submitted: 06.04.2014 Accepted after revision: 11.05.2015
}

Correspondence: DDr. Tülin Akarsu Ayazoğlu. SB Medeniyet Üniversitesi Göztepe Eğitim araştırma Hastanesi, Anestezi ve Reanimasyon Kliniği, Göztepe, İstanbul.

Tel: +90 - 216- 5664000 e-mail: akarsu.dr@gmail.com

(c) 2015 Turkish Society of Algology 


\section{Introduction}

Improving efficiency of perioperative management becomes more important in the modern practice of anaesthesiology by using intravenous (IV) and regional anesthesia with either general anesthesia or peripheral nerve blockades..$^{[1,2]}$ Epidural analgesia and general endotracheal anaesthetic techniques can be valuable adjuvants to fast-track anesthesia techniques for major surgery, providing a rapid recovery from anesthesia; it thereby facilitates early discharge from the hospital and allows rapid return to normal activities of daily life after ambulatory surgery. ${ }^{[3-5]}$ The benefits of epidural analgesia are most apparent when it is used as part of a multimodal analgesic regimen. ${ }^{[6,7]}$

A total IV anesthesia (TIVA) regimen with remifentanil and propofol have been turning out to be an alternative to inhalation anesthesia because of no accumulation, rapid induction feature and effectively controlling responses to tracheal intubation and allowing for rapid emergence from anesthesia without prolonged respiratory depression. ${ }^{[8-10]}$ TIVA is well documented with regard to effect, tolerability and safety. ${ }^{[11-14]}$

Combination of epidural and general anesthesia is proposed to be associated with more rapid recovery, ${ }^{[15,16]}$ reduced blood loss, ${ }^{[17]}$ reduced risk of venous thrombosis, ${ }^{[18]}$ early mobilization of the patient ${ }^{[19,20]}$ and shortened stay in intensive care units. ${ }^{[19,21,22]}$

The bispectral index score (BIS) has been proven to correlate well with the hypnotic state of the patient during both inhaled and IV anesthesia. ${ }^{[23]}$ The recommended target range for the BIS value during surgical anesthesia is between forty and sixty. [24] The BIS monitor is used to reduce the risk of intraoperative awareness ${ }^{[25]}$ and to guide administration of anaesthetics to prevent unnecessarily deep anesthesia resulting with prolonged recovery time.

In this study, we investigated the effects of combined epidural analgesia with TIVA and TIVA on the intraoperative hemodynamic response, induction doses (IDs), maintenance doses (MDs), drug consumption, recovery, patient satisfaction and cost.

\section{Materials and Methods}

The study protocol was approved by the Local Ethics Committee and all patients provided written informed consent forms.

This study consisted of 60 consecutive patients with American Society of Anaesthesiologists (ASA) classification III and undergoing major abdominal surgery expected to last at least 4 hours. The patients were randomized into 2 groups (Group E; epidural administration group $(n=30)$ and Group $C$; control group $(n=30)$ in a blind fashion.

Exclusion criteria were patients with age $<60$ years, $A S A<$ III or ASA $>$ III, patients undergoing emergent operation, patients with known coagulation disorders, neuraxial pathology, and patients having general contraindications for epidural anesthesia including patients' refusal, known hypersensitivity to the study drugs, preoperative analgesic and hypnotic usage, those receiving B-blockers, and those with a history of drug allergy or abuse and left ventricular ejection fraction $<30 \%$.

Gender, age, weight, and height of the included patients were recorded. On arrival at the operating room (OR), patients were received $10 \mathrm{~mL} /$ $\mathrm{kg}$ of IV Lactated Ringer's (LR) solution. Routine monitorization was performed by using electrocardiogram (ECG), pulse oximetry, invasive blood pressure measurements and urine output. After then patients were sedated with midazolam $1 \mathrm{mg}$, an epidural catheter was inserted through a 17 Gauge Tuohy needle at T12-L1 intervertebral space using the median approach with the loss of resistance technique and advanced $3-4 \mathrm{~cm}$. The patients were placed in the supine position. Group $\mathrm{E}$ was induced by epidural administration of $0.166 \%$ bupivacaine $+10 \mu \mathrm{g} / \mathrm{mL}$ fentanyl (bolus 8-10 ml) firstly and the same solution volume as the bolus of normal saline (NS) was administered in group C by epidural catheter. Ten minutes later, motor and sensory blocks were assessed by Bromage Scale ${ }^{[26]}$ (0-4) and pinprick.

The anaesthesiologist performing the epidural block and setting the epidural infusion was not aware of the group allocation. Another independent anaesthesiologist prepared all epidural injections. 
Table 1. Demographic data, durations of anaesthesia and surgery, site of surgery and pre-existing medical conditions of the patients by groups

\begin{tabular}{|c|c|c|c|c|c|c|}
\hline & \multicolumn{3}{|c|}{ Group $E(n=30)$} & \multicolumn{3}{|c|}{ Group C $(n=30)$} \\
\hline & $\mathbf{n}$ & $\%$ & Mean \pm SD & $\mathbf{n}$ & $\%$ & Mean \pm SD \\
\hline Age (Years) & & & $71 \pm 9.8$ & & & $68 \pm 10$ \\
\hline Male & 22 & 73 & & 21 & 70 & \\
\hline Female & 8 & 27 & & 9 & 30 & \\
\hline \multicolumn{7}{|l|}{ Mean durations (Minutes) } \\
\hline Anesthesia & & & $317 \pm 58.3$ & & & $308.3 \pm 43.1$ \\
\hline Surgery & & & $279.7 \pm 57.5$ & & & $270.7 \pm 46.5$ \\
\hline \multicolumn{7}{|l|}{ Site of surgical procedure } \\
\hline Esophagogastric & 5 & 16.6 & & 6 & 20 & \\
\hline Hepatobiliary/Pancreatic & 4 & 13.2 & & 6 & 20 & \\
\hline Bowel & 20 & 66.6 & & 8 & 60 & \\
\hline Other & 1 & 3.3 & & 0 & 0 & \\
\hline \multicolumn{7}{|l|}{ Co-Morbidities } \\
\hline Morbid obesity & 0 & 0 & & 1 & 3.3 & \\
\hline Chronic obstructive lung disease & 11 & 36.6 & & 9 & 30 & \\
\hline \multicolumn{7}{|l|}{ History of myocardial infarction } \\
\hline (History of coronary bypass or stenting included) & 3 & 9.9 & & 2 & 6.6 & \\
\hline Diabetes mellitus & 5 & 16.6 & & 4 & 13 & \\
\hline Hypertension & 2 & 6.6 & & 1 & 3.3 & \\
\hline Smoking habit & 3 & 9.9 & & 1 & 3.3 & \\
\hline
\end{tabular}

SD: Standard deviation.

BIS was monitored by using BIS VISTA ${ }^{\text {TM }}$ (Aspect Medical Systems Inc., Norwood, MA, USA) throughout the procedure and the operation.

An initial bolus of remifentanil $(0.5 \mu \mathrm{g} / \mathrm{kg})$ and $1 \mathrm{mg} /$ $\mathrm{kg}$ of propofol with lidocaine $(20 \mathrm{mg})$ was administered to all patients; then incremental doses of propofol $20 \mathrm{mg}$ for every 30 seconds were given until the BIS value reached $40-50$, endotracheal intubation was facilitated by rocuronium $0.6 \mathrm{mg} / \mathrm{kg}$. The doses of propofol required for induction were noted.

After endotracheal intubation, the epidural catheter was connected to an infusion pump that delivered $0.15 \mathrm{ml} / \mathrm{kg} / \mathrm{h}$ of $0.1 \%$ bupivacaine $+2 \mu \mathrm{g} / \mathrm{mL}$ fentanyl in group $\mathrm{E}$. In group C; NS was administered by epidural catheter with same infusion rate. General anesthesia was maintained with oxygen/air (50\%/50\%) and propofol administration of $40-150 \mu \mathrm{g} / \mathrm{kg} / \mathrm{min}$ was titrated to maintain BIS between 40 and 50 , and patients were given remifentanil maintenance dose of $0.15-1.0 \mu \mathrm{g} / \mathrm{kg} / \mathrm{min}$.
Subclavian central venous pressure catheter was also inserted.

Inadequate analgesia was defined as an increase in systolic blood pressure (SBP) and/or heart rate (HR) by $>20 \%$ of baseline values for at least 5 minutes in response to a surgical stimulus. In cases of inadequate analgesia; patients were treated with bolus remifentanil $1 \mu \mathrm{g} / \mathrm{kg}$. Additional bolus doses of rocuronium were injected if necessary.

At the end of the study period, maintenance dose requirements of propofol and remifentanil were calculated by dividing the total amount of the individual drug used for maintenance by duration of the study period (h) and patient's weight in kilograms, thus giving the individual drug consumption in $\mu \mathrm{g} /$ $\mathrm{kg} / \mathrm{h}$.

Bradycardia was defined as HR under 40/minute and hypotension as a decrease of $20 \%$ of base line in SBP. Bradycardia was treated by atropine $0.01 \mathrm{mg} / \mathrm{kg}$ and 
Table 2. Side effects according to patient groups

\begin{tabular}{lcccccc}
\hline & \multicolumn{2}{c}{ Group E } & & \multicolumn{2}{c}{ Group C } & p \\
\cline { 2 - 3 } & $\mathbf{n}$ & $\%$ & & $\mathbf{n}$ & $\%$ & \\
\hline Side effect & & & & & \\
$\quad$ Bradycardia & 0 & 0 & & 0 & 0 & \\
Hypotension & 3 & 10 & & 0 & 0 & $\mathbf{0 . 3 5 4}$ \\
Shivering & 1 & 3.3 & & 6.6 & \\
Tachycardia & 0 & 0 & & 3.3 & \\
\hline
\end{tabular}

hypotension was treated by infusion of LR solution and, if necessary, with administration of $5 \mathrm{mg}$ ephedrine by IV route. The frequencies of hypotension, hypertension and bradycardia were recorded.

MAP via arterial line, $\mathrm{HR}, \mathrm{O}_{2}$ Saturation $\left(\mathrm{SPO}_{2}\right)$, central venous pressure and BIS measurements were recorded as baseline, on the $1^{\text {st }}, 5^{\text {th }}, 10^{\text {th }}, 15^{\text {th }}, 20^{\text {th }}, 30^{\text {th }}$, $45^{\text {th }}, 60^{\text {th }}, 75^{\text {th }}, 90^{\text {th }}, 120^{\text {th }}, 150^{\text {th }}, 200^{\text {th }}, 250^{\text {th }}, 300^{\text {th }}$ and $350^{\text {th }}$ minutes after intubation and on the $5^{\text {th }}, 15^{\text {th }}$ and $30^{\text {th }}$ minutes after the end of the operation. During operation, the amount of consumed propofol and remifentanil were recorded. Time of extubation, time of eye opening with audible warning and time of verbal response were recorded as minutes.

At the end of surgery, all anaesthetics (remifentanil, propofol) were stopped simultaneously without previous tapering, and ventilation was controlled with 6 $\mathrm{L} /$ min of oxygen until the return of spontaneous ventilation. The extubation was performed after determination of adequate spontaneous ventilation (tidal volume of $4 \mathrm{~mL} / \mathrm{kg}$ ) and patient's response to verbal commands. The time of eye opening, hand pressing, spontaneous breathing, tracheal extubation, recalling name, date of birth, and getting a Modified Aldrete's Recovery Score ${ }^{[27]}$ over 9 were measured. Any intra and post anesthesia adverse events or experiences were assessed and recorded. Complications, morbidity and mortality in 30 days and after 30 days were recorded.

The statistical analyses were performed using software Statistical Package for Social Sciences ${ }^{\circledast}$ version 15.0 (SPSS $^{\circledast}$, IBM ${ }^{\circledR}$ Corp., Armonk, NY, USA). The Kolmogorov Smirnov test was used to evaluate whether the variables were normally distributed. The Continuous variables are presented as mean \pm Standard De- viation (SD) or as median (interquartile range). The unpaired Student-t test and Chi-square tests were used for comparisons of normally distributed continuous variables and categorical variables in two groups. The Mann-Whitney $U$ test was used for abnormally distributed variables. Bivariate correlation analyses were made using Pearson and Spearman correlation tests. A p value $<0.05$ was considered as statistically significant.

\section{Results}

There were 63 patients included in this study, but 3 of them were excluded from the group $C$ because of intraoperative hypertension requiring the administration of fentanyl and IV nitro-glycerine. The groups were compared according to demographic data, the duration of anesthesia, duration of surgery, site of surgery and pre-existing medical conditions (Table 1).

There was no significant difference between the groups according to the side effects of protocols $(p=0354)$. The observed side effects were hypotension in 3 patients from group $E$ vs. none from group C, shivering in 3 patients from group E vs. 2 patients from group $C$ and tachycardia in 1 patient from group $C$ vs. none from group $E$ (Table 2).

The mean interval for beginning of spontaneous respiration after cessation of propofol infusion was significantly shorter in group $E$ than group $C(p=0.016)$. The mean time for adequate respiration sign was also significantly earlier in group $E(p<0.001)$. There was no significant difference in mean duration to eye opening with audible warning between two groups ( $p=0.136$ ). We also found that the durations from cessation of propofol infusion to extubation $(p=0.003)$, verbal response $(p=0.009)$ and full recovery of modified Aldrete's score $(p<0.001)$ were significantly shorter in group $\mathrm{E}$ than group C (Table 3 ).

MAP on the baseline ( $p=0.982)$ and 1st minute after intubation $(p=0.106)$ were not significantly different between two groups. However, the MAP values of group $E$ were significantly lower than values of group $C$ on the $5^{\text {th }}(p=0.041), 10^{\text {th }}(p=0.013), 15^{\text {th }}(p=0.001)$, $20^{\text {th }}(p<0.001), 25^{\text {th }}(p<0.001), 30^{\text {th }}(p<0.001), 45^{\text {th }}$ $(p<0.001), 60^{\text {th }} \quad(p=0.001), 90^{\text {th }} \quad(p=0.001), 120^{\text {th }}$ $(p<0.001), 150^{\text {th }}(p<0.001), 200^{\text {th }}(p<0.001), 250^{\text {th }}$ $(p<0.001), 300^{\text {th }}(p=0.002)$ and $350^{\text {th }}(p=0.005)$ min- 
Table 3. Recovery steps by groups

\begin{tabular}{lcccc}
\hline & Group C & & Group E & p \\
\cline { 2 - 2 } & Mean \pm SD & & Mean \pm SD & \\
\hline Spontaneous respiration & $3.8 \pm 0.8$ & & $3.1 \pm 0.6$ & $\mathbf{0 . 0 1 6}$ \\
Adequate respiration & $6.6 \pm 0.9$ & & $5 \pm 0.7$ & $<\mathbf{0 . 0 0 1}$ \\
Eye opening with audible stimulus & $7 \pm 1$ & $6.5 \pm 1.1$ & 0.136 \\
Verbal response & $8.2 \pm 1.4$ & & $7.1 \pm 1$ & $\mathbf{0 . 0 0 9}$ \\
Extubation & $7.4 \pm 1.5$ & $6.3 \pm 1$ & $\mathbf{0 . 0 0 3}$ \\
10 for Aldrete's Score & $12.8 \pm 2.5$ & $9.4 \pm 2.3$ & $<\mathbf{0 . 0 0 1}$ \\
\hline
\end{tabular}

SD: Standard deviation.

utes after intubation as well as on the $5^{\text {th }}(p<0.001)$, $15^{\text {th }}(p<0.001)$ and $30^{\text {th }}(p<0.001)$ minutes after the end of the operation.

When we evaluated the MAP values for each group separately, there were statistically significant differences in group $C$ between different stages of the procedure as baseline value vs. post intubation 1st minute, $10^{\text {th }}$ minute vs. $15^{\text {th }}$ minute, $200^{\text {th }}$ minute vs. $250^{\text {th }}$ minute, $250^{\text {th }}$ minute vs. $300^{\text {th }}$ minute and postoperative $5^{\text {th }}$ minute vs. $15^{\text {th }}$ minute ( $p<0,05$ for each) (Figure 1).

In group $E$, we found that the differences of MAP values were significant for the stages as baseline vs. post intubation $1^{\text {st }}$ minute, $10^{\text {th }}$ minute vs. $15^{\text {th }} \mathrm{min}$ ute, $15^{\text {th }}$ minute vs. $20^{\text {th }}$ minute, postoperative $5^{\text {th }}$ minute vs. $15^{\text {th }}$ minute and $15^{\text {th }}$ minute vs. $30^{\text {th }}$ minute ( $p<0.05$ for each) (Figure 1).

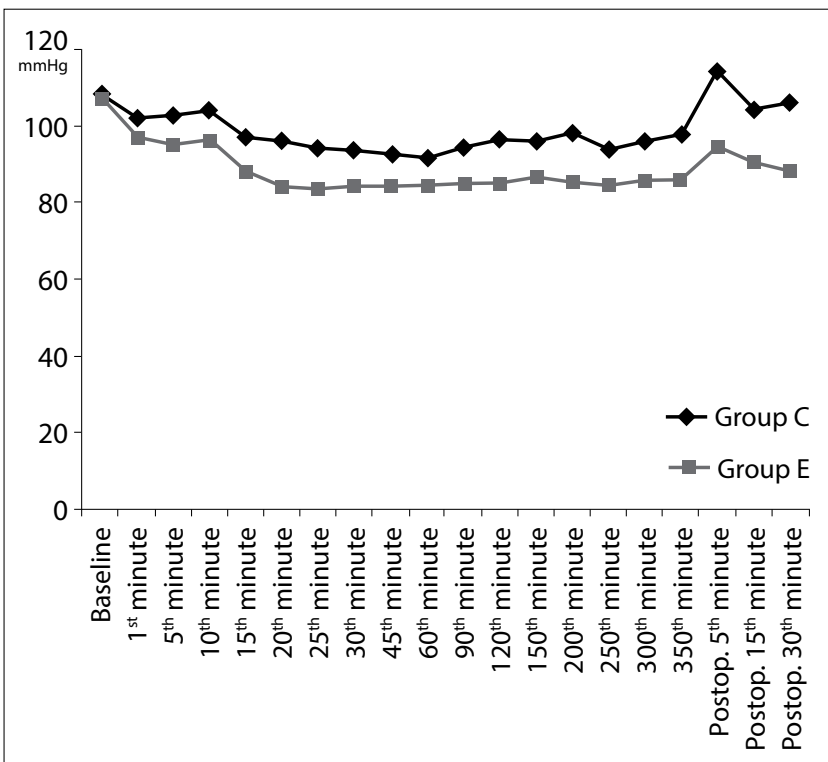

Figure 1. MAP values on timeline by groups.
There was no significant difference determined for $\mathrm{SPO}_{2}$ between group $\mathrm{E}$ and group $\mathrm{C}$ on any period $(p<0.05)$ except on $300^{\text {th }}$ minute $(p=0.021)$ (Table 4$)$.

We didn't find any significant difference for HR between two groups except on $300^{\text {th }}$ minute after intubation $(p=0.012)$, postoperative $5^{\text {th }}(p<0.001), 15^{\text {th }}$ $(p<0.001)$ and $30^{\text {th }}(p<0.001)$ minutes which were significantly lower in group $\mathrm{E}$ than in group $\mathrm{C}$ (Table 5) (Figure 2).

When we examined HR for each group, there were statistically significant differences in group $C$ between different stages of the procedure as baseline value vs. post intubation $1^{\text {st }}$ minute, $1^{\text {st }} \mathrm{vs}$. $5^{\text {th }}, 5^{\text {th }} \mathrm{vs}$. $10^{\text {th }}, 10^{\text {th }}$ vs. $15^{\text {th }}, 300^{\text {th }}$ vs. $350^{\text {th }}$ minutes, $350^{\text {th }}$ vs. postoperative $5^{\text {th }}$ minute, postoperative $5^{\text {th }}$ vs. $15^{\text {th }}$ and $15^{\text {th }}$ vs. $30^{\text {th }}$ minutes ( $<<0.05$ for each).

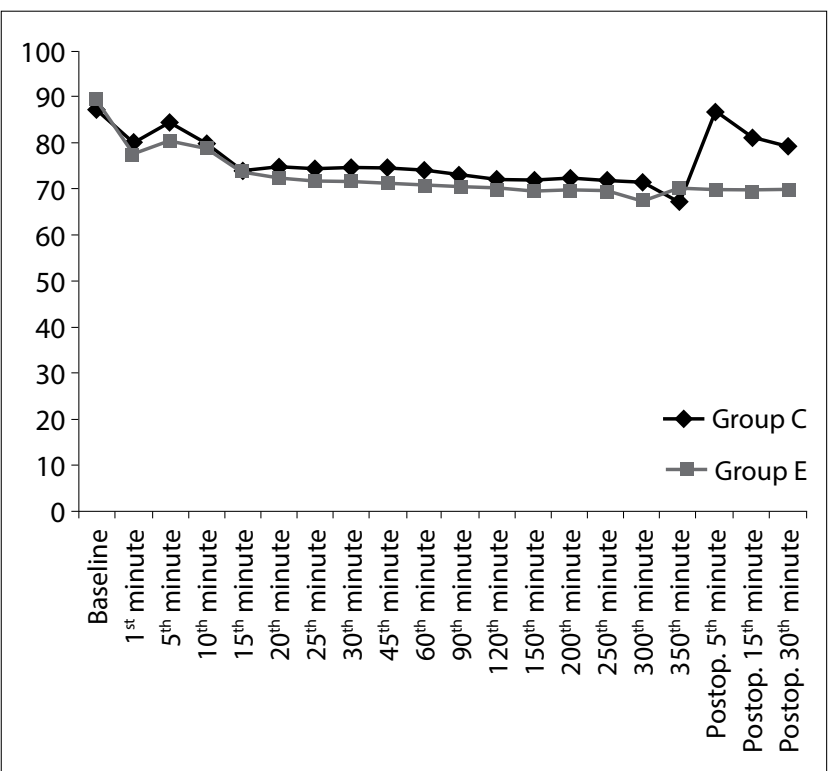

Figure 2. Heart rates on timeline by groups. 
Table 4. $\mathrm{SPO}_{2}$ on timeline by groups

\begin{tabular}{|c|c|c|c|}
\hline & $\frac{\text { Group C }}{\text { Mean } \pm \text { SD }}$ & $\frac{\text { Group E }}{\text { Mean } \pm \text { SD }}$ & $\mathbf{p}$ \\
\hline Baseline & $97.5 \pm 1.3$ & $97.5 \pm 1.4$ & 0.932 \\
\hline \multicolumn{4}{|l|}{ Post intubation } \\
\hline $1^{\text {st }}$ minute & $99.3 \pm 0.7$ & $99.5 \pm 0.6$ & 0.239 \\
\hline $5^{\text {th }}$ minute & $99.4 \pm 0.8$ & $99.3 \pm 0.8$ & 0.775 \\
\hline $10^{\text {th }}$ minute & $99.3 \pm 0.8$ & $99.3 \pm 0.8$ & 0.904 \\
\hline $15^{\text {th }}$ minute & $99.3 \pm 0.8$ & $99.5 \pm 0.7$ & 0.455 \\
\hline $20^{\text {th }}$ minute & $99.3 \pm 0.8$ & $99.5 \pm 0.7$ & 0.446 \\
\hline $25^{\text {th }}$ minute & $99.3 \pm 0.8$ & $99.5 \pm 0.7$ & 0.446 \\
\hline $30^{\text {th }}$ minute & $99.3 \pm 0.8$ & $99.5 \pm 0.7$ & 0.446 \\
\hline $45^{\text {th }}$ minute & $99.3 \pm 0.8$ & $99.5 \pm 0.7$ & 0.455 \\
\hline $60^{\text {th }}$ minute & $99.3 \pm 0.8$ & $99.5 \pm 0.7$ & 0.446 \\
\hline $90^{\text {th }}$ minute & $99.3 \pm 0.8$ & $99.5 \pm 0.7$ & 0.455 \\
\hline $120^{\text {th }}$ minute & $99.3 \pm 0.8$ & $99.3 \pm 0.7$ & 0.981 \\
\hline $150^{\text {th }}$ minute & $99.3 \pm 0.8$ & $99.4 \pm 0.7$ & 0.808 \\
\hline $200^{\text {th }}$ minute & $99.3 \pm 0.8$ & $99.4 \pm 0.7$ & 0.808 \\
\hline $250^{\text {th }}$ minute & $99.1 \pm 0.7$ & $99.1 \pm 0.6$ & 0.867 \\
\hline $300^{\text {th }}$ minute & $100.0 \pm 2.3$ & $99.1 \pm 0.5$ & 0.021 \\
\hline $350^{\text {th }}$ minute & $99.1 \pm 0.7$ & $98.9 \pm 0.4$ & 0.333 \\
\hline \multicolumn{4}{|l|}{ Postoperative } \\
\hline $5^{\text {th }}$ minute & $97.9 \pm 0.8$ & $97.9 \pm 0.8$ & 0.646 \\
\hline $15^{\text {th }}$ minute & $98.1 \pm 0.6$ & $98.1 \pm 0.8$ & 0.932 \\
\hline $30^{\text {th }}$ minute & $98.0 \pm 0.9$ & $98.0 \pm 0.9$ & 0.950 \\
\hline
\end{tabular}

SD: Standard deviation.

In group E; we found that the differences of HR were significant for the stages as baseline vs. post intubation $1^{\text {st }}$ minute and $10^{\text {th }}$ minute vs. $15^{\text {th }}$ minute $(p<0.05$ for each).

The epidural analgesia had a significant effect on propofol and remifentanil requirement. Requirement of propofol for IDs (to provide $B I S=45$ ) and MDs (to provide $B I S=40-50$ ) significantly reduced in the group $E$ than in group $C(p<0.001$ for each). The MDs of remifentanil significantly reduced in the group $E$ than in the group $C(p<0.001)$. Total propofol and remifentanil consumptions were significantly lower in group $E$ than in Group $C(p<0.001)$ (Table 6). During surgical anesthesia, propofol requirements in patients receiving bupivacaine were reduced by approximately $\% 34$ and similarly remifentanil approximately reduced by $\% 25$.
Table 5. Heart rates on timeline by groups

\begin{tabular}{|c|c|c|c|}
\hline & $\frac{\text { Group C }}{\text { Mean } \pm \text { SD }}$ & $\frac{\text { Group E }}{\text { Mean士SD }}$ & $\mathbf{p}$ \\
\hline Baseline & $87.23 \pm 12.75$ & $89.47 \pm 11.35$ & 0.553 \\
\hline \multicolumn{4}{|l|}{ Post Intubation } \\
\hline $1^{\text {st }}$ minute & $80.33 \pm 11.39$ & $77.83 \pm 9.27$ & 0.528 \\
\hline $5^{\text {th }}$ minute & $84.23 \pm 10.20$ & $80.50 \pm 6.50$ & 0.210 \\
\hline $10^{\text {th }}$ minute & $79.83 \pm 4.14$ & $78.97 \pm 4.61$ & 0.566 \\
\hline $15^{\text {th }}$ minute & $74.20 \pm 6.53$ & $74.07 \pm 6.43$ & 0.917 \\
\hline $20^{\text {th }}$ minute & $74.73 \pm 7.99$ & $72.57 \pm 9.04$ & 0.435 \\
\hline $25^{\text {th }}$ minute & $74.27 \pm 6.88$ & $71.77 \pm 7.51$ & 0.284 \\
\hline $30^{\text {th }}$ minute & $74.53 \pm 5.13$ & $71.63 \pm 6.80$ & 0.198 \\
\hline $45^{\text {th }}$ minute & $74.50 \pm 4.75$ & $71.40 \pm 6.27$ & 0.101 \\
\hline $60^{\text {th }}$ minute & $73.87 \pm 5.02$ & $70.83 \pm 5.80$ & 0.080 \\
\hline $90^{\text {th }}$ minute & $73.03 \pm 4.53$ & $70.63 \pm 5.48$ & 0.140 \\
\hline $120^{\text {th }}$ minute & $72.07 \pm 4.50$ & $70.13 \pm 5.10$ & 0.248 \\
\hline $150^{\text {th }}$ minute & $71.80 \pm 4.41$ & $69.40 \pm 5.48$ & 0.113 \\
\hline $200^{\text {th }}$ minute & $72.37 \pm 4.60$ & $69.83 \pm 5.72$ & 0.154 \\
\hline $250^{\text {th }}$ minute & $71.80 \pm 4.30$ & $69.47 \pm 5.51$ & 0.114 \\
\hline $300^{\text {th }}$ Minute & $71.50 \pm 16.52$ & $67.58 \pm 7.47$ & 0.012 \\
\hline $350^{\text {th }}$ minute & $67.22 \pm 25.55$ & $70.25 \pm 7.76$ & 0.594 \\
\hline \multicolumn{4}{|l|}{ Postoperative } \\
\hline $5^{\text {th }}$ minute & $86.77 \pm 9.06$ & $69.83 \pm 4.96$ & $<0.001$ \\
\hline $15^{\text {th }}$ minute & $81.13 \pm 6.79$ & $69.80 \pm 5.42$ & $<0.001$ \\
\hline $30^{\text {th }}$ minute & $79.23 \pm 6.61$ & $69.83 \pm 5.11$ & $<0.001$ \\
\hline
\end{tabular}

SD: Standard deviation.

\section{Discussion}

Buchanan et al. ${ }^{[28]}$ proposed that gender has an independent effect on recovery times in patients undergoing general anesthesia. They concluded that women are less sensitive to the hypnotic effect of anaesthetic drugs than men and may help explain faster recovery times in women. Since the female/ male ratio was the same in this study, effect of gender on dose requirement was excluded.

It has been shown that TIVA application is quite successful in ambulatory and minor surgery, however there is less data related to the use of the short-acting anaesthetic IV agents with pre-emptive epidural analgesia in long lasting major abdominal surgery. The recommended doses of propofol for induction dose(ID) and maintenance dose(MD) of anesthesia are $1-2.5 \mathrm{mg} / \mathrm{kg}$ and $50-150 \mu \mathrm{g} / \mathrm{kg} / \mathrm{min}$, respectively. $[19,22,29,30]$ In this study, IDs of both groups for propofol 
Table 6. Drug consumption according to groups

\begin{tabular}{lcccc}
\hline & Group E & & Group C & p \\
& Mean \pm SD & & Mean \pm SD & \\
\hline Propofol & & & \\
$\quad$ Induction $(\mathrm{mg} / \mathrm{kg})$ & $1.2 \pm 0.3$ & & $1.9 \pm 0.4$ & $<\mathbf{0 . 0 0 1}$ \\
$\quad$ Maintenance $(\mu \mathrm{g} / \mathrm{kg} / \mathrm{min})$ & $47 \pm 10$ & & $73 \pm 12$ & $<\mathbf{0 . 0 0 1}$ \\
$\quad \begin{array}{l}\text { Total Amount }(\mathrm{mg}) \\
\text { Remifentanil }\end{array}$ & $1145.0 \pm 382.6$ & & $1714.7 \pm 269.7$ & $<\mathbf{0 . 0 0 1}$ \\
$\quad$ Maintenance $(\mu \mathrm{g} / \mathrm{kg} / \mathrm{min})$ & $0.18 \pm 0.02$ & & $0.25 \pm 0.09$ & $<\mathbf{0 . 0 0 1}$ \\
Total Amount $(\mathrm{mg})$ & $4.2 \pm 0.6$ & & $5.6 \pm 1.2$ & $<\mathbf{0 . 0 0 1}$ \\
\hline
\end{tabular}

SD: Standard deviation.

were established compatible with these mentioned limits. However propofol ID was found significantly low in group E. Besides, propofol anesthesia MDs in group $C$ was established in mentioned limits but found significantly higher than that in group $E$. In Group E, propofol MD was found to be significantly lower than recommended dose interval.

The recommended remifentanil MD of propofol anesthesia is $0.05-2 \mu \mathrm{g} / \mathrm{kg} / \mathrm{min} .{ }^{[31,32]}$ The requirements of remifentanil during maintenance of anesthesia in both groups were within the recommended range of remifentanil infusion. In our study, remifentanil MDs was found to be significantly lower in group $E$ than that in group $C$.

Choosing the most appropriate dose of local anaesthetics is one of the most important factors in providing the balance between pain control and adverse event. Bupivacaine, a local anaesthetic, administered via epidural catheter can be used in doses as low as $0.0625-0.125 \% .^{[33,34]}$ High doses more than $0.15 \%$ of bupivacaine via epidural route may cause adverse events such as motor block, orthostatic hypotension. . $^{[35,36]}$

Casati et al. ${ }^{[37]}$ examined MAP and BIS during induction. They found a significantly increase after intubation, by $18 \%$ and $49 \%$ respectively; a larger increase in BIS was seen. Changes in MAP reflect the neuroendocrine response to pain and this response mainly blocked by the induction drugs (thiopental or IV Iidocaine). They conclude that epidural bupivacaine does not alter the thiopental dose, but it decreases isoflurane requirements by $35 \%$. This study demon- strates that both doses of bupivacaine and fentanyl induce similar isoflurane-sparing effects. However, patients receiving $0.125 \%$ bupivacaine showed lower values of MAP when compared with controls, and thus bupivacaine $0.0625 \%$ should be favoured during combined anesthesia.

Whitehead E et al. ${ }^{[38]}$ used ropivacaine $0.5 \%, 0.75 \%$ and $1.0 \%$ in an open study of extradural anesthesia in three groups of 15 patients undergoing urological or orthopaedic surgery. Analgesia was satisfactory for surgery in all patients except for one in the $0.75 \%$ group. Hypotension was experienced by three patients in the $0.5 \%$ group, seven patients in the $0.75 \%$ group and three patients in the $1.0 \%$ group. Bradycardia occurred in seven patients and was associated with hypotension in five. Backache was experienced after operation by four patients.

It is also concluded in a previous study (examining the influence of epidural morphine on the endtidal sevoflurane concentration) that there was no significant difference between groups for end-tidal sevoflurane concentrations at identical BIS values and hemodynamic values at any time in the study. ${ }^{[39]}$ Zhao et al. ${ }^{[40]}$ investigated the hemodynamic effects between the two established Anesthetic managements: thoracic epidural anesthesia combined with general anesthesia (TEA+GA) as well as TIVA. The patients received TEA with $0.25 \%$ bupivacaine (bolus $0.5 \mathrm{mg} / \mathrm{kg}$ firstly and then infused continuously with $0.2 \mathrm{ml} / \mathrm{kg} / \mathrm{h}$ ). In TIVA group, the patients received $0.9 \%$ saline via epidural catheter just with the same bolus volume and same infusion rate as in TEA+GA group. After epidural infusion of bupiva- 
caine (TEA+GA group) or saline (TIVA group), systolic arterial pressure (SAP), diastolic arterial pressure (DAP), HR and systemic vascular resistance (SVR) in TEA+GA group were statistically decreased in comparing with the baseline, and SAP, DAP, MAP and SVR were also decreased significantly when compared with those in TIVA group ( $p<0 r=0.05$ ). However, cardiac index and SVR in TEA+GA group changed little and showed no statistical differences in comparing with those in TIVA group. This study gives evidences that TEA in combination with GA had no negative effects on cardiac functions. The decrease of blood pressure may possibly be caused by the reduction of systemic vascular resistance.

A previous retrospective study examined the influence of age on hemodynamic parameters and awakening time in TIVA combined with continuous epidural anesthesia for abdominal surgery. They suggested that the combination of TIVA and continuous epidural anesthesia would be useful to maintain stable hemodynamic state and to obtain early recovery time, especially in the elderly. ${ }^{[23-25,28,30,41]}$ The combination of TIVA and epidural anesthesia does not require the use of intraoperative intravenous opioids and shortens recovery time without increasing the incidence of side effects ${ }^{[41-43]}$ and reduce the dose consumption of IV and inhalation anaesthetics. ${ }^{[44-46]}$

We used $0.1 \%$ bupivacaine combined with $2 \mu \mathrm{g} /$ $\mathrm{mL}$ fentanyl infusion doses in our study, and found that MAP values on $10^{\text {th }} \mathrm{min}$. after intubation and on $5^{\text {th }}, 15^{\text {th }}, 30^{\text {th }}$ min. after extubation were statistically lower in group $\mathrm{E}$ than in group $\mathrm{C}$. However, in both groups, hemodynamic stability was provided in the same way as others studies. Although HR showed decrease in both groups, there was no perioperative difference determined between two groups.

In our study we also found that in major abdominal surgery that lasts more than four hours: the durations of spontaneous breathing after cessation of anesthesia, adequate breathing, verbal response, extubation, orientation and the duration to maintain full Aldrete's score were significantly shorter in group $E(p<0,01)$.

There was no relation between application methods and complication, morbidity, mortality. There was not any serious adverse event caused by anesthesia and we found no difference in the incidence of any major complication or death between TIVA and epidural combined with TIVA groups.

Data regarding TIVA or TIVA+epidural anesthesia in long lasting major abdominal surgery is insufficient. We investigated the effect of epidural analgesia with TIVA on the intraoperative hemodynamic response, IDs and MDs, recovery (as evaluated by using the bispectral index BIS), drug consumption. Significant reduction in the dose requirement of propofol for induction and maintenance of anesthesia was observed along with a reduction in MDs of remifentanil in the patients who received pre-emptive epidural analgesia. Based on lower requirements for propofol and remifentanil, we conclude that BIS guided combined epidural with TIVA is superior to TIVA in this type of surgery.

\section{Conflict-of-interest issues regarding the authorship or article: None declared.}

\section{Peer-rewiew: Externally peer-reviewed.}

\section{References}

1. Kehlet H. Multimodal approach to control postoperative pathophysiology and rehabilitation. $\mathrm{Br} J$ Anaesth 1997;78(5):606-17.

2. Kehlet $H$, Dahl JB. Anaesthesia, surgery, and challenges in postoperative recovery. Lancet 2003;362(9399):1921-8.

3. White PF, Kehlet H, Neal JM, SchrickerT, Carr DB, Carli F; FastTrack Surgery Study Group. The role of the anesthesiologist in fast-track surgery: from multimodal analgesia to perioperative medical care. Anesth Analg 2007;104(6):1380-96.

4. Kehlet $H$, Wilmore DW. Evidence-based surgical care and the evolution of fast-track surgery. Ann Surg 2008;248(2):189-98.

5. Klein J. Multimodal multidisciplinary standardization of perioperative care: still a long way to go. Curr Opin Anaesthesiol 2008;21(2):187-90.

6. Mizutani A, Hattori S, Yoshitake S, Kitano T, Noguchi T. Effect of additional general anesthesia with propofol, midazolam or sevoflurane on stress hormone levels in hysterectomy patients, receiving epidural anesthesia. Acta Anaesthesiol Belg 1998;49(2):133-9.

7. Chernow B, Alexander HR, Smallridge RC, Thompson WR, Cook D, Beardsley D, et al. Hormonal responses to graded surgical stress. Arch Intern Med 1987;147(7):1273-8.

8. Dauri M, Costa F, Servetti S, Sidiropoulou T, Fabbi E, Sabato AF. Combined general and epidural anesthesia with ropivacaine for renal transplantation. Minerva Anestesiol 
2003;69(12):873-84.

9. Agarwal A, Pandey R, Dhiraaj S, Singh PK, Raza M, Pandey $C K$, et al. The effect of epidural bupivacaine on induction and maintenance doses of propofol (evaluated by bispectral index) and maintenance doses of fentanyl and vecuronium. Anesth Analg 2004;99(6):1684-8.

10. Sinha PK, Unnikrishnan KP. Reduction in requirement of propofol during combined epidural (bupivacaine) and general anesthesia guided by bispectral index. Anesth Analg 2005;101(2):613-4.

11. Egan TD. Remifentanil pharmacokinetics and pharmacodynamics. A preliminary appraisal. Clin Pharmacokinet 1995;29(2):80-94.

12. Patel SS, Spencer CM. Remifentanil. Drugs 1996;52(3):41728.

13. Smith I, White PF, Nathanson M, Gouldson R. Propofol. An update on its clinical use. Anesthesiology 1994;81(4):100543.

14. Schmidt J, Hering W, Albrecht S. Total intravenous anesthesia with propofol and remifentanil. Results of a multicenter study of 6,161 patients. [Article in German] Anaesthesist 2005;54(1):17-28. [Abstract]

15. Dunet F, Pfister Ch, Deghmani M, Meunier Y, DemeilliersPfister G, Grise P. Clinical results of combined epidural and general anesthesia procedure in radical prostatectomy management. Can J Urol 2004;11(2):2200-4.

16. Li Y, Zhu S, Yan M. Combined general/epidural anesthesia (ropivacaine $0.375 \%$ ) versus general anesthesia for upper abdominal surgery. Anesth Analg 2008;106(5):1562-5.

17. O'Connor PJ, Hanson J, Finucane BT. Induced hypotension with epidural/general anesthesia reduces transfusion in radical prostate surgery. Can J Anaesth 2006;53(9):873-80.

18. Delis KT, Knaggs AL, Mason P, Macleod KG. Effects of epidural-and-general anesthesia combined versus general anesthesia alone on the venous hemodynamics of the lower limb. A randomized study. Thromb Haemost 2004;92(5):1003-11.

19. De Cosmo G, Congedo E, Lai C, Sgreccia M, Amato A, Beccia $\mathrm{G}$, et al. Ropivacaine vs. levobupivacaine combined with sufentanil for epidural analgesia after lung surgery. Eur J Anaesthesiol 2008;25(12):1020-5.

20. Burmeister MA, Gottschalk A, Freitag M, Horn EP, Böhme C, Becker $C$, et al. Pre- and intraoperative epidural ropivacaine have no early preemptive analgesic effect in major gynecological tumour surgery. Can J Anaesth 2003;50(6):56873.

21. Von Dossow V, Welte M, Zaune U, Martin E, Walter M, Rückert J, et al. Thoracic epidural anesthesia combined with general anesthesia: the preferred anesthetic technique for thoracic surgery. Anesth Analg 2001;92(4):848-54.

22. Bardram L, Funch-Jensen $P$, Jensen $P$, Crawford ME, Kehlet $H$. Recovery after laparoscopic colonic surgery with epidural analgesia, and early oral nutrition and mobilisation. Lancet 1995;345(8952):763-4.

23. Glass PS, Bloom M, Kearse L, Rosow C, Sebel P, Manberg $P$. Bispectral analysis measures sedation and memory effects of propofol, midazolam, isoflurane, and alfentanil in healthy volunteers. Anesthesiology 1997;86(4):836-47.

24. Gan TJ, Glass PS, Windsor A, Payne F, Rosow C, Sebel P, et al. Bispectral index monitoring allows faster emergence and improved recovery from propofol, alfentanil, and nitrous oxide anesthesia. BIS Utility Study Group. Anesthesiology 1997;87(4):808-15.

25. Myles PS, Leslie K, McNeil J, Forbes A, Chan MT. Bispectral index monitoring to prevent awareness during anaesthesia: the B-Aware randomised controlled trial. Lancet 2004;363(9423):1757-63.

26. Bromage Pr, Burfoot Mf, Crowell De, Pettigrew Rt. Quality of Epidural Blockade. I. Influence of Physical Factors. Br J Anaesth 1964;36:342-52.

27. Soliman IE, Patel RI, Ehrenpreis MB, Hannallah RS. Recovery scores do not correlate with postoperative hypoxemia in children. Anesth Analg 1988;67(1):53-6.

28. Buchanan FF, Myles PS, Leslie K, Forbes A, Cicuttini F. Gender and recovery after general anesthesia combined with neuromuscular blocking drugs. Anesth Analg 2006;102(1):291-7.

29. Reves JG, PS; Lubarsky DA. Nonbarbiturate intravenous anesthetics. In: Miller RD, editor. Anesthesia. Philadelphia: Churchill Livingstone 2000. p. 228-72.

30. Vuyk J, Mertens MJ, Olofsen E, Burm AG, Bovill JG. Propofol anesthesia and rational opioid selection: determination of optimal EC50-EC95 propofol-opioid concentrations that assure adequate anesthesia and a rapid return of consciousness. Anesthesiology 1997;87(6):1549-62.

31. Scott LJ, Perry CM. Remifentanil: a review of its use during the induction and maintenance of general anaesthesia. Drugs 2005;65(13):1793-823.

32. Bürkle $H$, Dunbar $S$, Van Aken H. Remifentanil: a novel, short-acting, mu-opioid. Anesth Analg 1996;83(3):646-51.

33. Shir Y, Raja SN, Frank SM. The effect of epidural versus general anesthesia on postoperative pain and analgesic requirements in patients undergoing radical prostatectomy. Anesthesiology 1994;80(1):49-56.

34. Subramaniam B, Pawar DK, Kashyap L. Pre-emptive analgesia with epidural morphine or morphine and bupivacaine. Anaesth Intensive Care 2000;28(4):392-8.

35 Liu SS, Carpenter RL, Mackey DC, Thirlby RC, Rupp SM, Shine TS, et al. Effects of perioperative analgesic technique on rate of recovery after colon surgery. Anesthesiology 1995;83(4):757-65.

36. Badner NH, Reid D, Sullivan P, Ganapathy S, Crosby ET, McKenna J, et al. Continuous epidural infusion of ropivacaine for the prevention of postoperative pain after major orthopaedic surgery: a dose-finding study. Can J Anaesth 1996;43(1):17-22.

37. Casati L, Fernández-Galinski S, Barrera E, Pol O, Puig MM. Isoflurane requirements during combined general/epidural anesthesia for major abdominal surgery. Anesth Analg 2002;94(5):1331-7.

38. Whitehead E, Arrigoni B, Bannister J. An open study of ropivacaine in extradural anaesthesia. $\mathrm{Br} J$ Anaesth 1990;64(1):67-71.

39. Koo M, Sabaté A, Dalmau A, Camprubi I. Sevoflurane re- 
quirements during coloproctologic surgery: difference between two different epidural regimens. J Clin Anesth 2003;15(2):97-102.

40. Zhao W, Zhou R, Zhou LP, Li CH. The hemodynamic effects during thoracic epidural anesthesia combined with general anesthesia in patients undergoing major abdominal operations. [Article in Chinese] Zhonghua Wai Ke Za Zhi 2009;47(11):849-52. [Abstract]

41. Tabuchi Y. The influence of age on hemodynamics and the dose requirements of propofol and buprenorphine in total intravenous anesthesia combined with continuous epidural anesthesia. [Article in Japanese] Masui 2001;50(8):8426. [Abstract]

42. Handley GH, Silbert BS, Mooney PH, Schweitzer SA, Allen NB. Combined general and epidural anesthesia versus general anesthesia for major abdominal surgery: postanesthesia recovery characteristics. Reg Anesth 1997;22(5):435-41.
43. Luchetti M, Palomba R, Sica G, Massa G, Tufano R. Effectiveness and safety of combined epidural and general anesthesia for laparoscopic cholecystectomy. Reg Anesth 1996;21(5):465-9.

44. Hodgson PS, Liu SS. Epidural lidocaine decreases sevoflurane requirement for adequate depth of anesthesia as measured by the Bispectral Index monitor. Anesthesiology 2001;94(5):799-803.

45. Lu CH, Borel CO, Wu CT, Yeh CC, Jao SW, Chao PC, et al. Combined general-epidural anesthesia decreases the desflurane requirement for equivalent $A$-line $A R X$ index in colorectal surgery. Acta Anaesthesiol Scand 2005;49(8):1063-7.

46. Tverskoy M, Shifrin V, Finger J, Fleyshman G, Kissin I. Effect of epidural bupivacaine block on midazolam hypnotic requirements. Reg Anesth 1996;21(3):209-13. 